Wyższa Szkoła Gospodarki Euroregionalnej

im. Alcide De Gasepri w Józefowie

ms@wsge.edu.pl

Matgorzata Such-Pyrgiel

Wyższa Szkoła Gospodarki Euroregionalnej

im. Alcide De Gasperi w Józefowie

m.such-pyrgiel@hotmail.com

\title{
INFLUENCE OF CYBERCULTURE ON HUMAN RIGHTS
}

\section{WPŁYW CYBERKULTURY NA PRAWA CZŁOWIEKA}

\begin{abstract}
The subject of the study is the issue of the need to create culture in cyberspace. The cyberspace opens many opportunities for people which facilitate everyday life and also supports the functioning of the society. The aim of this studies is to show the impact of cyberspace on human rights, their perception, respect, but also on the new possibilities of breaking them. Apart from preliminary considerations and the explanation of the importance of basic concepts, two examples of violations and possible counteracting violations of human rights (the right to health and freedom of speech) have been discussed. The conclusion of this study is the belief that traditional measures, i.e. statutory restrictions and monitoring mechanisms, are insufficient. It is necessary to undertake a broad educational campaign aimed at promoting the principles of good use of the benefits of cyberspace. The result of these activities will be the emerging cyberculture.

\section{STRESZCZENIE}

Przedmiotem opracowania jest problematyka potrzeby kreowania kultury w cyberprzestrzeni. Cyberprzestrzeń otwiera przed człowiekiem wiele nowych możliwości, które ułatwiają codzienne życie, a także wspiera funkcjonowanie społeczeństwa. Celem pracy jest ukazanie wpływu cyberprzestrzeni na prawa człowieka, ich spostrzeganie, respektowanie, ale też na nowe zagrożenia ich łamania. Poza rozważaniami wstępnymi i wyjaśnieniem znaczenia podstawowych pojęć, omówione zostały dwa przykłady łamania praw człowieka i możliwego przeciwdziałania naruszeniom prawa do zdrowia i wolności słowa. Wnioskiem wynikającym z niniejszego badania jest przekonanie o tym, że tradycyjne środki, tj. ograniczenia ustawowe oraz mecha-
\end{abstract}


nizmy monitorowania są niewystarczające. Konieczne jest podjęcie szerokiej kampanii edukacyjnej nakierowanej na promowanie zasad dobrego korzystania $\mathrm{z}$ dobrodziejstwa, jakim jest cyberprzestrzeń. Efektem tych działań będzie tworząca się cyberkultura.

KEYWORDS: cyberspace, human rights, internet, cyber threats, education, cyberculture

SŁOWA KLUCzOWE: cyberprzestrzeń, prawa człowieka, Internet, zagrożenia w cyberprzestrzeni, edukacja, cyberkultura

\section{WPROWADZENIE}

Począwszy od lat osiemdziesiątych XX wieku, można odnotować powolny wzrost zainteresowania różnych badaczy kwestiami cyberkultury. W konsekwencji w literaturze naukowej znajdują się publikacje, które w samym tytule mają zastosowany termin „cyberkultura”. Przykładem może być publikacja J. Janowskiego (Janowski, 2012, 35 i n.; Turner, 2010; Silver, 2004, s. 55-64).

Przedmiotem niniejszego opracowania jest analiza wybranych obszarów granicznych pomiędzy cyberprzestrzenią a prawami człowieka. To, jakie możliwości wnosi cyberprzestrzeń dla rozwoju ludzkości, rodzi pytanie o rolę człowieka w tej nowej wirtualnej - czy może już jak najbardziej realnej - rzeczywistości. Przeciętny Polak korzysta z internetu po 2 godziny i 6 minut dziennie, co w skali roku daje więcej niż jeden miesiąc (Polacy spędzają..., 2018). Funkcjonowanie człowieka w cyberprzestrzeni siłą rzeczy zaczyna tworzyć elementy cyberkultury. Stąd hipotezą badawczą tej publikacji jest twierdzenie, według którego człowiek w tej nowej rzeczywistości jest bardziej traktowany przedmiotowo niż podmiotowo. Dowodem tego jest skala naruszeń praw człowieka w internecie. Wnioskiem końcowym zaś powinno być kreowanie kultury w cyberprzestrzeni przyjaznej człowiekowi.

\section{Podstawowe POJĘCIA}

Przybliżenie kwestii, czy może analiza wpływu cyberprzestrzeni na treść praw człowieka wymaga zdefiniowania podstawowych pojęć niezbędnych 
dla dalszego dyskursu naukowego, a zwłaszcza pojęć powszechnie dzisiaj używanych, nierzadko w różnych językach i odmianach. Takiego zdefiniowania wymaga samo pojęcie „cyberprzestrzeń”, które w języku angielskim brzmi: cyberspace. Terminem powiązanym $\mathrm{z}$ nim funkcjonalnie, ale mający treściowo odmienne znaczenie, jest słowo „cyberkultura”.

Cyberkultura jest przeciwieństwem tego, o czym najczęściej mówi się podczas konferencji naukowych, posiedzeń rządów, kierownictwa agencji publicznych i prywatnych odpowiadających za bezpieczeństwo, a mianowicie przeciwieństwem zagrożeń (cyber threats), jakie z niesie ze sobą cyberprzestrzeń dla człowieka, społeczeństwa czy struktur państwa (Kałdoń, 2016, s. 87 i n; Ertoz, 2003, s. 51 i n.). Takie dość negatywne podejście do cyberprzestrzeni determinuje również działania ustawodawcy krajowego (Ustawa z dnia 5 lipca 2018 r. o krajowym systemie cyberbezpieczeństwa (Dz.U. z 2018 r. poz. 1560) i międzynarodowego (Rozporządzenie Parlamentu Europejskiego i Rady w sprawie „Agencji UE ds. Cyberbezpieczeństwa” ENISA, uchylenia rozporządzenia (UE) nr 526/2013 oraz certyfikacjicyberbezpieczeństwawzakresietechnologiiinformacyjno-komunikacyjnych, COM/2017/0477 final/3 - 2017/0225(COD) (Wasilewski, 2013, s. 225 i n.; Zawisza, 2015, s. 404).

\section{Cyberprzestrzeń}

Pojęcie cyberprzestrzeń zostało po raz pierwszy użyte przez W. Gibsona w 1982 r. w jego powieści Burning Chrome. Pisarz ten cyberprzestrzeń określił jako konsensualna halucynacja. Takie literackie rozumienie cyberprzestrzeni nie odpowiada definicjom funkcjonującym w dokumentach urzędowych. I tak, Department Obrony Narodowej Stanów Zjednoczonych zdefiniował pojęcie cyberprzestrzeń jako: A global domain within the information environment consisting of the interdependent network of information technology infrastructures and resident data, including the Internet, telecommunications networks, computer systems, and embedded processors and controllers (Department of Defense).

$\mathrm{Z}$ kolei w polskich aktach prawnych definicja pojęcia cyberprzestrzeni znajduje się w przepisie art. 2 ust. 1a ustawy z dnia 21 czerwca 2002 o stanie wyjątkowym (Dz.U. z 2017 r. poz. 1928), w którym ustawodawca postano- 
wił, że Przez cyberprzestrzeń, o której mowa $w$ ust. 1, rozumie się przestrzeń przetwarzania $i$ wymiany informacji tworzona przez systemy teleinformatyczne, określone $w$ art. 3 pkt 3 Ustawy $z$ dnia 17 lutego 2005 r. o informatyzacji działalności podmiotów realizujacych zadania publiczne (Dz.U. z 2017 r. poz. 570), wraz z powiązaniami pomiędzy nimi oraz relacjami $z$ użytkownikami. Wszystkie powyższe definicje zwierają podobne elementy oraz takie, które nawzajem się uzupełniają. To, co je łączy, to to, że bazą istnienia cyberprzestrzeni są systemy teleinformatyczne.

Narzędzia teleinformatyczne pozwalają na wymianę, gromadzenie, przetwarzanie, poszukiwanie czy udostępnianie informacji, ale też na ich wytwarzanie niekiedy w sposób niekontrolowalny lub trudno kontrolowalny przez jakiekolwiek organy państwowe czy międzynarodowe. Istotnym elementem cyberprzestrzeni jest komunikowanie się ludzi ponad wszelkimi granicami politycznymi, ekonomicznymi, społecznymi czy kulturowymi. Jeszcze do niedawna cyberprzestrzeń określano jako świat wirtualny. Tymczasem, że względu na przeniesienie wielu aktywności człowieka do internetu, jak nawiązywanie kontaktów, poszukiwanie informacji, rozrywki, załatwianie bieżących spraw, np. opłacanie comiesięcznych rachunków, rezerwowanie hotelu czy wizyty u lekarza, zakup biletu czy nawet produktów żywnościowych, cyberprzestrzeń staje się wirtualną rzeczywistością, w której człowiek realnie żyje (Niedziółka, 2014, 418).

Cyberprzestrzeń wywiera ogromny wpływ na człowieka, jego sytuację zawodową, majątkową, na pozycję społeczną, znajomości, kontakty czy możliwości. To nie gazety tradycyjnie drukowane czy telewizja, lecz internet stał się instrumentem kreującym dobrą lub złą sławę jednostki, tak osoby fizycznej, jak i prawnej. Przeszukując dane, które są zgromadzone w cyberprzestrzeni, można dość dobrze nakreślić portret psychologiczny nieomalże każdego użytkownika internetu. Wielu ma wątpliwości, czy wprowadzona Dyrektywa unijna RODO jest w stanie uporządkować kwestię jakości treści w cyberprzestrzeni (Rozporządzenie Parlamentu Europejskiego i Rady (UE) 2016/679 z dnia 27 kwietnia 2016 r. w sprawie ochrony osób fizycznych w związku $\mathrm{z}$ przetwarzaniem danych osobowych i w sprawie swobodnego przepływu takich danych oraz uchylenia dyrektywy 95/46/WE; ogólne rozporządzenie o ochronie danych). 


\section{Cyberkultura}

Drugim terminem wymagającym zdefiniowania jest cyberkultura. Podstawowe pytanie, na jakie należy poszukać odpowiedzi, dotyczy tego, czy w ogóle można mówić o cyberkulturze, a jeśli już, to jaką może mieć formę jej jakość.

Samo pojęcie kultura jest wieloznaczne, stąd w literaturze naukowej można znaleźć niezliczoną ilość definicji tego pojęcia. Nawet Słownik oksfordzki kulturę definiuje w sposób opisowy, wskazując, że jest to sposób życia danej społeczności i jej organizacji. Przejawem tego sposobu są wartości wierzenia, sztuka, nauka, zwyczaje, budowle itp. (Blackburn, 1997, s. 206). Przyjmując za prawdziwe powszechne przekonanie (opinio communis), że za wytwór kultury uznaje się to wszystko, co jest efektem działalności człowieka, można stwierdzić, iż cyberprzestrzeń jest również elementem kultury. Nie tylko sama cyberprzestrzeń jest elementem kultury. Cyberprzestrzeń jest środowiskiem, w którym jest tworzona nowa co do formy i jakości kultura (Ilnicki, 2015, s. 135).

P. Lévy pisze, że cyberkultura jest zestawem technologii, składającym się z elementów materialnych i intelektualnych, praktyk, zwyczajów, sposobów myślenia i wartości, których rozwój uzależniony jest od rozwoju cyberprzestrzeni (Lévy, 2001, s. XVI). Cybekultura ułatwia zarządzanie zagrożeniami w cyberprzestrzeni (Kumar, Sricastava i Lazarabic, 2006, s. 45).

\section{Cyberkultura JAKO WARUNEK RESPEKTOWANiA PRAW CZLOWIEKA}

Przedstawiciel Amnesty International USA W.F. Schultz twierdzi, że cyberprzestrzeń może być instrumentem wspomagającym łamanie praw człowieka. Przykładem tego jest wykorzystywanie internetu do handlu ludźmi czy komunikowana się między pedofilami. Członkowie tzw. państwa islamskiego ISSI przy pomocy internetu werbowali w Europie ochotników do walki w ich szeregach, a także młode dziewczęta na żony bojowników. Osoby, którym udało się opuścić szeregi bojowników, opisywali dokonywania permanentnego łamania praw człowieka. Zwerbowane zaś dziewczęta najczęściej były obiektem licznych nadużyć seksualnych (Sitek, 2017, s. 257 i n.; Novikowa, 2013, s. 106 i n.). 
Internet może jednak być też instrumentem służącym do organizowania się społeczeństwa do przeprowadzenia zmian politycznych, społecznych czy też znacząco może przyczynić się do położenia tamy przeciwko łamaniu praw człowieka. Można tutaj przytoczyć wiele przykładów budowania solidarności międzyludzkiej dzięki stosowaniu urządzeń tworzących cyberprzestrzeń, np. zorganizowanie w 2002 r. w Stanach Zjednoczonych akcji społecznych przeciwko stosowaniu tortur (FAST - Fast Action Stops Torture) (Schultz, 2002, s. 94 i n.). W dalszej części zostaną omówione dwa przykłady dotyczące prawa do zdrowia i prawa do wolności słowa z perspektywy cyberprzestrzeni.

\section{Prawo do zdrowia}

Zdrowie człowieka jest niewątpliwie jednym z podstawowych praw człowieka, a jednocześnie i jego potrzeb. W zachodniej kulturze organizacji państwa dość szeroko zostały zagwarantowane możliwości zaspokojenia tej potrzeby. Stworzony został system publicznej opieki medycznej oraz pomocy społecznej. Gwarancje prawne dla realizacji tego prawa znajdują się w prawie międzynarodowym oraz polskim. Taką gwarancję można znaleźć w przepisie art. 68 Konstytucji RP oraz w licznych ustawach, np. Ustawa z dnia 19 sierpnia 1994 r. o ochronie zdrowia publicznego (Dz.U. z 2018 r. poz. 1878). Obowiązek troski o zdrowie spoczywa na państwie, systemach ubezpieczenia czy też na agencjach rządowych, którym powierzono realizację jakieś części zadań publicznych, np. w Polsce jest to Narodowy Fundusz Zdrowia (Ustawa z dnia 27 sierpnia 2004 r. o świadczeniach opieki zdrowotnej finansowanych ze środków publicznych - Dz.U. z 2018 r. poz. 1510).

Ustawodawca kwestię bezpieczeństwa i reklam produktów leczniczych uregulował w ustawie $\mathrm{z}$ dnia 27 lutego 2008 r. Prawo farmaceutyczne (Dz.U. z 2017 r. poz. 2211) (dalej: p.f.). Pieczę nad bezpieczeństwem produktów leczniczych powierzył Prezesowi Urzędu Produktów Leczniczych. Ten, na podstawie przepisu art. 3 ust. 1 wydaje pozwolenie na dopuszczenie do obrotu produktów leczniczych. Pozwolenie takie na terytorium Polski ex lege mają również produkty, które posiadają odpowiednie pozwolenie wydane przez Radę Unii Europejskiej lub Komisję Europejską (art. 3 ust. 2 p.f.). Takich pozwoleń nie potrzebują leki recepturowe, apteczne, produkty radiofarmaceutyczne, krew i osocze i produkty lecznicze terapii zaawansowanej (art. 3 ust. 4 p.f.). 
Zasady reklamy produktów leczniczych zostały uregulowane w rozdziale 4 ustawy Prawo farmaceutyczne (art. 52-64). Z przepisu art. 52 p.f. wynika, że ustawodawca nie różnicuje w swojej regulacji sposobu reklamowania, a więc przepisy te obejmują również reklamę produktów leczniczych w internecie. Niezwykle ważny przepis to art. 53 p.f., w którym znalazły się zasady dotyczące reklamy produktów leczniczych. Do ważniejszych zasad reklamy produktów leczniczych należy zaliczyć:

- reklama nie może wprowadzać w błąd, czyli musi być obiektywna,

- reklama nie może oferować lub obiecywać jakichkolwiek korzyści w zamian za nabycie produktu leczniczego,

- reklama nie może być kierowana do dzieci,

- reklama produktu leczniczego, poza jego nazwą własną i nazwą powszechnie stosowaną, może zawierać tylko znak towarowy niezawierający odniesień do wskazań leczniczych, postaci farmaceutycznej, dawki, haseł reklamowych lub innych treści reklamowych,

Nie jest dopuszczalna reklama produktów leczniczych, które nie są dopuszczone do obrotu na terytorium Polski (art. 56 ust. 1 p.f.).

W uproszczonym zarysie zostały przedstawione zasady reklamy produktów leczniczych w Polsce. Reklama niezgodna z nimi może być zakazana lub niedozwolona. W obu przypadkach łamanie zasad reklamy zagrożone jest jedynie karą grzywny. Reklamą zakazaną jest prowadzenie reklamy produktów leczniczych przez podmioty nieuprawnione, czyli takie, które nie mają stosownego pozwolenia od prezesa urzędu lub reklamują produkty niedopuszczone do obrotu w Polsce (art. 129 p.f.). Reklamą niedozwoloną jest promowanie produktów wydawanych na podstawie recepty, produktu którego nazwa jest identyczna $z$ tym wydawanym na receptę, promowanie produktów zawierających środki odurzające lub substancje psychotropowe. Niedozwolone jest reklamowanie produktów o nazwie identycznej do leków refundowanych (art. 129a p.f.) (Walczak, 2016, s. 125).

Ten, wydawać by się mogło, spokojny stan prawny i organizacyjny może być i nierzadko jest zaburzany przez aktywność człowieka w cyberprzestrzeni. Przeszukując jakikolwiek portal informacyjny, można natknąć się na re- 
klamy leków czy usług medycznych połączonych z poradami medycznymi. Nie są to jednak proste reklamy o charakterze informacyjnym. Najczęściej są tak pisane, aby kształtować świadomość słuchacza, niestety nierzadko błędnie. Przykładem mogą być reklamy leków, które mają całkowicie zlikwidować szum w uszach albo powodować ustanie bólu czy też obniżenie wagi. Analogicznie reklamowane są usługi medyczne, które według reklamodawców mają szybko usuwać problemy zdrowotne.

Ta stosunkowo nowa forma reklamy lekarstw czy usług medycznych z wykorzystaniem instrumentów cyberprzestrzeni, zwłaszcza internetu, może powodować mylne wyobrażenia o metodach leczenia, środkach leczniczych, mogących być stosowanymi z pominięciem konsultacji z lekarzem. Kładzenie nacisku w reklamie na natychmiastowe działanie leku dostosowywane jest i kierowane do bardzo skonkretyzowanych potrzeb czytającego. Celem odpowiednio przygotowanej reklamy jest wzbudzenie w potencjalnym konsumencie przekonania o nieporadności służby zdrowia, trafności wyboru oraz oszczędności czasu i pieniędzy. Treść reklamy sugeruje, że można sobie samemu pomóc bez pomocy lekarza.

Nowe możliwości reklamy środków medycznych z wykorzystaniem instrumentów cyberprzestrzeni rodzi jednak kwestię odpowiedzialności za szkody wyrządzone handlem środkami leczniczymi bez stosownych pozwoleń i kontroli. W tradycyjnym systemie dość łatwo można zidentyfikować autora reklamy, w internecie często jest to bardzo trudne lub wręcz niemożliwe. Stosowanie w tym przypadku przepisu art. 415 k.c. dotyczącego odpowiedzialności za szkody wyrządzone deliktem raczej jest mało prawdopodobne z dwóch powodów (Krekora, Świerczyński i Traple, 2008). Po pierwsze sprawca, który wprowadza do cyberprzestrzeni reklamę produktów leczniczych, najczęściej czyni to spoza Polski. Wprawdzie negatywny skutek powstaje na terenie Polski, to jednak dochodzenie odszkodowania za szkodę, a de facto za krzywdę, przed sądem polskim, a następnie jego egzekucja na podstawie rozporządzenia Parlamentu Europejskiego i Rady (UE) nr 1215/2012 z dnia 12 grudnia 2012 r. w sprawie jurysdykcji i uznawania orzeczeń sądowych oraz ich wykonywania w sprawach cywilnych i handlowych, tzw. „Brukselę I bis", jest mało prawdopodobna. Drugi powód to ten, że w przypadku szkody powstałej w skutek użycia niedopuszczonych do obrotu handlo- 
wego produktów leczniczych powstaje krzywda, nie zaś klasyczna szkoda (Szczęsny, 2010, s. 15 i n.; Białecki, 2003, s. 9 i n.; Świerczyński, 2003, s. 55).

Rodzi się zatem pytanie o środki zaradcze w zwalczaniu nieuczciwej reklamy środków medycznych. Moim zdaniem w celu zapobieżenia reklamy produktów leczniczych niedopuszczonych do obrotu handlowego należałoby wyposażyć Prezesa Urzędu Rejestracji Produktów Leczniczych w możliwość blokowania stron promujących leki bez pozwolenia. Drugim sposobem uporządkowania jest wprowadzenie ujednoliconego systemu prawnego przynajmniej w Unii Europejskiej, który pozwałby na wymierzanie surowszych kar administracyjnych. Unia, wprawdzie w tytule VIII Dyrektywy 2001/83/WE Parlamentu Europejskiego i Rady z dnia 6 listopada 2001 r. w sprawie wspólnotowego kodeksu odnoszącego się do produktów leczniczych stosowanych u ludzi (Dz. Urz. WE L 311 z 28.11.2001, s. 67-128) wprowadziła przepisy dotyczące reklamy produktów leczniczych, nie ma w nich jednak odniesienia do reklamy w cyberprzestrzeni.

W przypadku zaś zdiagnozowania uszkodzenia zdrowia środkiem leczniczym niedopuszczonym do obrotu sądy powinny mieć możliwość zastosowania rozwiązania pochodzącego $\mathrm{z}$ amerykańskiego systemu prawnego, a mianowicie instytucji punitive damages. Instytucja ta pozwala na orzeczenie przez sąd wielokrotności odszkodowania na rzecz pokrzywdzonego. Celem takiego działania jest prewencja, czyli przesłanie skierowane do innych, które chciałby prowadzić zakazaną lub niedozwoloną reklamę produktów leczniczych. W końcu chyba najbardziej skutecznym środkiem może być szeroka edukacja społeczna na temat mechanizmów reklamy zakazanej czy niedozwolonej w internecie oraz o możliwych środkach zaskarżenia w przypadku doznania krzywdy. Mogłaby to być kampania podobna do walki z nałogiem palenia papierosów. Edukacja w cyberprzestrzeni dotycząca właściwego odbioru reklam środków leczniczych przez internautów może być istotnym elementem cyberkultury (Hersch i Viscusi, 2002, s. 2 i n.).

\section{Wolność słowa}

Jednym z praw człowieka, które pod wpływem zjawiska cyberprzestrzeni podlega znaczącemu poszerzeniu, jest wolność słowa. Ta wolność gwarantowana jest w licznych aktach prawa międzynarodowego, w tym w Europejskiej 
Konwencji o Ochronie Praw Człowieka i Podstawowych Wolności. Już w preambule do Powszechnej Deklaracji praw Człowieka z 1948 r. stwierdzono, że po II wojnie światowej należy dążyć do zbudowania świata opartego na wolności słowa i przekonań. Z kolei w przepisie art. 9 i 10 Europejskiej Konwencji Praw Człowieka została zagwarantowana wolność myśli, sumienia i wyznania oraz wolność wyrażania opinii. Analogiczne postanowienia znalazły się w przepisie art. 10 i 11 Karty Praw Podstawowych Unii Europejskiej z 2000 r. (Dz.U. U.E. z 26.10.2012 C. 326/391). Polski ustrojodawca kwestię wolności słowa oraz jego wyrażania na zewnątrz uregulował w art. 53 i 54 Konstytucji RP oraz w licznych ustawach.

W świetle powyższych przepisów prawa wolność słowa obejmuje wolność posiadania poglądów, wyrażania ich na zewnątrz, o ile nie są prawem zakazane. Należy jednak zdawać sobie sprawę z tego, że przepisy te były pisane w czasie, gdy nie było internetu, a niewielu myślało o czymś takim jak cyberprzestrzeń. Jeszcze w latach 90. ubiegłego wieku nie można było sobie wyobrazić dzisiejszych sposobów realizacji wolności słowa oraz możliwości jej nadużywania.

W literaturze wskazuje się na cztery etapy nadużyć wolności słowa w internecie. Pierwsza faza polegała na rozpowszechnianiu treści pornograficznych, zwłaszcza z udziałem dzieci. W przeciwdziałaniu temu zjawisku Microsoft stworzył bazę elektronicznych podpisów, dzięki czemu można łatwo usuwać treści o charakterze pornograficznym. Kolejnym etapem był trolling. Dzięki anonimowości w sieci można było gnębić psychicznie czy oczerniać inne osoby, które nierzadko w obliczu fali hejtu popełniały samobójstwo. W walce $\mathrm{z}$ tym zjawiskiem platformy internetowe monitorują działania użytkowników i w przypadku zgłoszenia hejtu mogą takie działania blokować. Niestety, nie jest to środek wystarczająco skuteczny. Konsekwencją trollingu jest mowa nienawiści, z którą też trudno jest sobie poradzić.

Kolejnym etapem nadużyć wolności słowa w internecie to działania organizacji terrorystycznych działających przez internet, $\mathrm{z}$ wykorzystaniem komunikatorów społecznościowych. W ten sposób rozsiewają swoją ideologię, wzywając do solidarności z nimi (Przemysł niszczenia wizerunku..., 2018). Działania te mają znaczące skutki polityczne. Media światowe donoszą o możliwym wpłynięciu na wyniki wyborów w Stanach Zjednoczonych poprzez działania służb rosyjskich w internecie. 
Obecnie można zauważyć nowe zjawisko, czyli niszczenie reputacji przeciwnika handlowego, politycznego czy nielubianego kolegi poprzez rozpowszechnianie w internecie nieprawdziwych informacji lub informacji prawdziwych, ale przekazanych w sposób negatywny (reputational exploitation). Taką akcję prowadzi się również wobec państw, w tym i Polski. W internecie można znaleźć liczne przykłady artykułów, w których przedstawiana jest historia odmiennie od tej powszechnie znanej. Autorzy tych informacji liczą na to, że teksty te będą czytane przez ludzi nieznających historii. Groźniejsze jednak skutki może wywołać dyskredytowanie np. obowiązkowych szczepień - skutkiem będzie wzrost ryzyka nawet pandemii jakieś groźnej choroby - czy też dyskredytowanie działań służby zdrowia przy jednoczesnym promowaniu paramedycyny - skutkiem może być wzrost śmiertelności powodowanej odmową przyjęcia fachowej pomocy medycznej.

Wpływ na wolność słowa ma również postawa reklamodawców i ich presja na promowanie w mediach, a zwłaszcza w cyberprzestrzeni określonych treści. Globalny czy wirtualny świat bilbordów uzależnia treść przekazu od wpływów z reklam. Stąd reklamodawcy mają interes w tym, aby kontrolować i uzależniać od siebie media czy treści zamieszczane w cyberprzestrzeni (Schuler i Day, 2003, s.74).

Wobec nowych możliwości technicznych dla realizacji prawa do wolności słowa oraz skali nadużyć podejmowane są różne działania. Platformy internetowe są dzisiaj zobowiązane do monitorowania treści na nich gromadzonych pod kątem treści pornograficznych, mowy nienawiści, trollingu czy innych negatywnych zjawisk, jak np. wpływanie na wyborców. Administratorzy mogą takie informacje blokować. Nie są to jednak środki wystarczające do obniżenia poziomu walki z nadużywaniem wolności słowa w internecie. Niewątpliwie środkiem wpierającym działania legislacyjne czy organizacyjne będzie edukacja skierowana do wszystkich grup społecznych, poczynając od dzieci, a kończąc na osobach starszych.

\section{Podsumowanie}

Cyberprzestrzeń tworzona za pomocą narzędzi teleinformatycznych stała się częścią życia człowieka. Wywiera ona wpływ na coraz to nowsze obszary aktywności człowieka. W ten sposób ułatwia się życie człowieka, a jednocze- 
śnie powstają nowe możliwości. Nowej jakości nabrały: komunikacja międzyludzka, organizacja wakacji, poszukiwania pracy, kontaktów w urzędami publicznymi czy edukacja.

Nowe możliwości, które daje zwłaszcza Internet, rodzi też nowe sposoby różnego rodzaju nadużyć, w tym finansowych, politycznych czy społecznych. Dość słabo zauważalne są nadużycia w zakresie praw człowieka. Można spotkać się z licznymi opracowaniami dotyczącymi poszczególnych przypadków łamania praw człowieka w cyberprzestrzeni, jak np. handel ludźmi czy pornografia dziecięca, brakuje jednak pogłębionej refleksji nad zjawiskiem jako takim, w tym nad środkami zaradczymi.

Poza kontrolą czy monitorowaniem treści zamieszczanych w cyberprzestrzeni, konieczna jest szeroko zakrojona kampania edukacyjna. Nie może ona mieć wyłącznie charakteru jednorazowej akcyjności, lecz musi być ona przemyślana, tak co do treści, jak i formy. Zachłyśnięcie się wolnością, jaką daje Internet, bo nadal ludzkość jest na tym etapie, musi rodzić refleksję nad tym, aby ta wolność nie była nadużywana w różnych obszarach. Nie wystarczają środki normatywne czy techniczne. Koniecznym elementem uzupełniającym będzie zatem permanentna edukacja korzystania z cyberprzestrzeni. Jej przygotowanie zajmie sporo czasu i wysiłku. Wydaje się jednak, że bez tej edukacji nie będzie możliwe zapewnienie bezpieczeństwa w cyberprzestrzeni.

\section{Literatura:}

Białecki, P. (2003). Reklama produktu leczniczego w świetle ustawy Prawo farmaceutyczne. Zagadnienia wybrane, „Przegląd Ustawodawstwa Gospodarczego”, nr 6, s. 9-16. ISSN 0137-5490.

Blackburn, S. (1997). Oksfordzki słownik filozoficzny, Warszawa: Książka i Wiedza. ISBN 835129209.

Department of Defense Dictionary of Military and Associated Terms, 8.11.2010 r. https://fas.org/irp/doddir/dod/jp1_02.pdf (dostęp: 28.10.2018).

Ertoz, L. et al. (2003). Protecting against cyber threats in networked information systems. W: R. Suresh, Battlespace Digitization and Network-Centric Systems III. „International Society for Optics and Photonics”, s. 51-57. ISBN 9780819449610.

Hersch, J., Viscusi, K.W., (2002). Punitive Damages: How Judges and Juries Perform, „Discussion Paper” nr 362/05, s. 1-38. ISSN 1045-6333. 
Ilnicki, R. (2015). Wirtualny habitus cyberkultury, „Hybris” nr 31/4, s. 133-154. ISSN 1689-4286.

Janowski, J. (2012). Cyberkultura prawa. Współczesne problemy filozofii i informatyki prawa, Warszawa: Difin. ISBN 9788376416557.

Kałdoń, B. (2016). Cyberprzestrzeń jako zagrożenie dla człowieka XXI wieku, „Seminare" nr 37/2, s. 87-101. ISSN 1232-8766.

Krekora, M. Świerczyński, M. Traple, E. (2008). Prawo farmaceutyczne. Zagadnienia regulacyjne i cywilnoprawne, Warszawa: Wolters Kluwer Polska. ISBN 9788376012001.

Kumar, V. Srivastava, J. Lazarevic, A. (red.) (2006). Managing cyber threats: issues, approaches, and challenges, cz. 5, Montreal: Springer Science \& Business Media, ISBN 9780387242309.

Lévy, P. (2001). Cyberculture, Minneapolis-London: University of Minnesota Press. ISBN 3540401563.

Niedziółka, I. (2014). Dziecko jako Konsument, „Journal of Modern Science” nr 20/1, s. 419-430. ISSN 1734-2031.

Novikowa, K. (2013). Izomorfizm: imitacja jako źródło zmiany instytucjonalnej, W: K. Novikowa, S. Ćmiel, Funkcjonowanie administracji publicznej - historia i stan obecny, Józefów: WSGE. ISBN 9788362753406.

Polacy spędzaja $w$ sieci średnio ponad miesiąc rocznie. W: Forbes, $26.03 .2018 \mathrm{r}$. https://www.forbes.pl/gospodarka/ile-czasu-polacy-spedzaja-w-sieci-danie-badanie-gemiuspbi/v9x22l2 (dostęp: 27.10.2018).

Przemystniszczenia wizerunku - nowezagrożeniezinternetu, https://wiadomosci.onet. $\mathrm{pl} /$ swiat/przemysl-niszczenia-wizerunku-nowe-zagrozenie-z-internetu/155zh6z (dostęp: 5.11.2018).

Schuler, D. Day, P. (red.) (2003). Shaping the network society: The new role of civil society in cyberspace, Cambridge: MIT Press. ISBN 9780262194976.

Schultz, W.F. (2002). Human Rights and Cyberspace, „New Perspectives Quarterly” nr 19.2, s. 94-97. ISSN 0893-7850

Silver, D. (2004). Internet/cyberculture/digital culture/new media/fill-in-the-blank studies. „New Media \& Society” nr 6.1, s. 55-64. ISSN 0893-7850.

Sitek, M. (2017). The human rights to communicate in the light of the development of IT technology at the turn of the XX and XXI centuries. W: M. Sitek, A.F. Uricchio, I. Florek (red.), Human rights between needs and possibilities, Józefów: WSGE, s. 257-270. ISBN 9788362753857. 
Szczęsny, R. (2010). Reklama farmaceutyczna i pokrewna, Warszawa: C.H. Beck. ISBN 9788325511159.

Świerczyński, M. (2003). Reklama produktów leczniczych według znowelizowanej ustawy - Prawo farmaceutyczne, „Monitor Prawniczy” nr 10, s. 453-460. ISSN1230-6509.

Turner, F. (2010). From counterculture to cyberculture: Stewart Brand, the Whole Earth Network, and the rise of digital utopianism. Chicago: University of Chicago Press. ISBN 9780226817422.

Walczak, M. (2016). Normatywne ograniczenia reklamy produktów leczniczych kierowanej do publicznej wiadomości, „Zeszyty Naukowe Towarzystwa Doktorantów UJ Nauki Społeczne", nr 4, s. 125-141. ISSN 2082-9213.

Wasilewski, J. (2013). Zarys definicyjny cyberprzestrzeni, „Przegląd Bezpieczeństwa Wewnętrznego" nr 5(9), s. 225-234. ISSN 2080-1335.

Zawisza, J. (2015). Cyberprzestrzeń jako zagrożenie bezpieczeństwa państwa, „Journal of Modern Science" nr 25/4, s. 403-416. ISSN 1734-2031.

\section{Źródła prawa}

Prawo międzynarodowe

Powszechna Deklaracja Praw Człowieka z dnia 10 grudnia 1948 r. Rezolucja Zgromadzenia Ogólnego ONZ 217 A.

Europejska Konwencja Praw Człowieka - dokument Rady Europy otwarty do podpisu 4 listopada $1950 \mathrm{r}$.

Karta Praw Podstawowych Unii Europejskiej z 2000 r. (Dz.U. U.E. z 26.10.2012 C. 326/391).

\section{Prawo Unii Europejskiej}

Rozporządzenie Parlamentu Europejskiego i Rady (UE) 2016/679 z dnia 27 kwietnia 2016 r. w sprawie ochrony osób fizycznych w związku z przetwarzaniem danych osobowych i w sprawie swobodnego przepływu takich danych oraz uchylenia dyrektywy 95/46/WE. (Dz.U. U.E. 20106 Nr L 119/1).

Rozporządzenie Parlamentu Europejskiego i Rady w sprawie „Agencji UE ds. Cyberbezpieczeństwa" ENISA, uchylenia rozporządzenia (UE) nr 526/2013 oraz certyfikacji cyberbezpieczeństwa w zakresie technologii informacyjno-komunikacyjnych. COM/2017/0477 final/3 - 2017/0225 (COD). 
Rozporządzenie Parlamentu Europejskiego i Rady (UE) nr 1215/2012 z dnia 12 grudnia 2012 r. w sprawie jurysdykcji i uznawania orzeczeń sądowych oraz ich wykonywania w sprawach cywilnych i handlowych (Dz.U. U.E. $2012 \mathrm{nr} 351 / 1$ ).

Dyrektywy 2001/83/WE Parlamentu Europejskiego i Rady z dnia 6 listopada 2001 r. w sprawie wspólnotowego kodeksu odnoszącego się do produktów leczniczych stosowanych u ludzi (Dz.U. WE $2001 \mathrm{nr}$ L 311).

\section{Prawo polskie}

Konstytucja Rzeczpospolitej Polskiej z dnia 2 kwietnia 2007 r. (Dz.U. 1997 nr 78, poz. 483).

Ustawa z dnia 5 lipca 2018 r. o krajowym systemie cyberbezpieczeństwa (Dz.U. 2018 poz. 1560).

Ustawa $z$ dnia 27 lutego 2008 r. Prawo farmaceutyczne (Dz.U. 2017 poz. 2211).

Ustawa z dnia 27 sierpnia 2004 r. o świadczeniach opieki zdrowotnej finansowanych ze środków publicznych (Dz.U. 2018 poz. 1510).

Ustawa z dnia 21 czerwca 2002 o stanie wyjątkowym (Dz.U. 2017 poz. 1928.

Ustawa z dnia 19 sierpnia 1994 r. o ochronie zdrowia publicznego (Dz.U. 2018 poz. 1878). 
